\title{
Effects of Industry-University Collaboration on Enterprises' Intellectual Capital: A Study of Hi-Tech Industries in Zhejiang, China
}

\author{
Ran Li \\ Doctor of Philosophy Program in Management, Shinawatra University \\ E-mail: 393515428@qq.com
}

Eksiri Niyomsilp

Dr, School of Management, Shinawatra University

Received: Jan. 25, 2020 Accepted: Feb. 14, 2020 Online published: Feb. 26, 2020

doi:10.5296/ijhrs.v10i1.16548ＵRL: https://doi.org/10.5296/ijhrs.v10i1.16548

\begin{abstract}
This study aims to explore the impact of industry-university collaboration on enterprises' intellectual capital. From the perspective of industry-university collaboration relationship management, to explore the influence of different industry-university collaboration relationship on the enterprises' intellectual capital. Survey was used to collect the data from 406 Zhejiang province hi-tech enterprises' entrepreneur and senior executives of the industry-university collaboration project using purposive sampling. Quantitative methods were used to analyze the variables and to test hypothesis.

Industry-university collaboration itself is a systematic project that needs close collaboration and coordination between the society and relevant units. The relationship between universities and enterprises plays an important role in collaboration. It has become an important obstacle of industry-university collaboration and a restriction factor of knowledge transfer. Therefore, industry-university collaboration cross-organizational management has gradually become a research hotpots for scholars. Taking high-tech enterprises in Zhejiang province as an example, this study studies the different effects of industry-university collaborative relations on enterprises' intellectual capital from the perspective of industry-university collaborative relations, and improves enterprises' intellectual capital through scientific and effective management of industry-university collaborative relations. On the basis of Tijssen, Perkmann, Walsh and other research achievements, this study divides
\end{abstract}


the industry-university collaboration into two types of relationship: related type and transactional type. Quantitative research method is adopted to analyze the variables and verify the hypothesis. According to the data analysis results, draw a conclusion: Industry-university collaboration relationship should be based on the related relationship, the enterprise with strong related relationship has higher intellectual capital performance. Finally, according to the research results, some Suggestions on the management of industry-university collaborative relationship are put forward for the reference of local governments and future researchers.

Keywords: industry-university collaboration, industry-university collaboration relationship, related relationship, transactional relationship, intellectual capital

\section{Introduction}

Nowadays the world is becoming a knowledge-based society; the storage and application of knowledge is the basis for economic growth and capital accumulation (Nonaka \& Takeuchi, 1995). As the core knowledge of the enterprise, intellectual capital is the key resource of the core competitiveness and competitive advantage of the enterprise. There are many ways to create innovations which are very importance as sources of intellectual property for the business and industry product and service developments. One approach which often used in Europe and in the USA is the company-funded collaboration in the research and development centers in the education institutions. This kind of activity aims to fulfill the need of both parties, industry and university where university needs fund to support its laboratory and the industry needs new knowledge and innovation for their product developments. Lately, industry- university collaboration is a core part of many countries' innovation systems (Porter,1999; OECD,1996). Industry-university collaboration itself is a systematic project, so it requires a close collaboration and coordination between the society and various relevant units. However, the relationships between university and enterprise plays an important role in collaboration; it is becoming an important obstacle to industry-university collaboration and a constraint on knowledge transfer (Bjerregard, 2014; Gassol, 2007).

Johnson (2008) mentioned that the three-helix collaboration (academia, government, and industry) is difficult to create and maintain because of differences in culture, organization, incentives, and goals. However, the author pointed out that this industry-university collaboration relationship is the key success factor of technological development for enterprises. Daghfous (2004) commented on the importance of collaboration between industries and universities as a fast and effective way to develop capabilities. Regarding the interests of enterprises, many scholars (Boardman, 2008) have demonstrated the phenomenal growth rate of companies that have their collaboration relationships with universities, compared to those that do not have a university relationship.

At present, China's industry-university collaboration mechanism is mainly through contractual collaboration methods such as technology transfer, cooperative development and commissioned development. It generally stays at the university to provide problem-oriented simple services to enterprises. Lack of long-term collaboration and strategic alliances makes it difficult to upgrade enterprises. Intellectual capital innovation, let alone the promotion of 
intellectual capital innovation for the entire industry, regional industries and even the country. A large number of industry-university collaboration practices show that universities and enterprises, as heterogeneous organizations, have not yet formed effective cooperative relationships in terms of strategy, organization, and resources. From this perspective, a university is a teaching - scientific - production - operational operating mechanism while an enterprise is an operational - production - scientific - educational operational mechanism or a user. Each party has to rely on each other for the supports of bringing new innovation into practices. Thus, the success of doing this is not only how deep is the collaboration, but it should be how long the collaboration will last.

In the process of industry-university collaboration, there are still many questions that need the answers such as what kind of relationship is concluded between the two parties, how to manage cross-organizational relationships, how to achieve university knowledge outputs, enterprises to acquire knowledge and transform into intellectual capital, continue to maintain competitive advantage, we need to explore through empirical research.

\section{Problem Background}

Since the Chinese governments place the importance of industry-university collaboration as high level policy, they need to apply the policy into practice. The National Development and Reform Commission of the Ministry of Education, and the Chinese Academy of Sciences have jointly launched the industry-university joint development project. In 1992, the Chinese government has already established a strategic goal of building an innovative country with industry-university collaboration as a breakthrough. At present, the government has introduced more than 3,000 policies to promote industry-university collaboration. However, from the actual results of industry-university collaboration and a large number of empirical studies found that the regulation effect of relevant policies on industry-university collaboration innovation is not obvious. From the news revealed regarding this issue found that the collaborations did not provide the good performance as the government expected. It can be summarized as five main aspects:

Collaboration Policies and Regulations. There are many macro policies to promote industry-university collaboration, but few fiscal and financial policies to promote the specificity of industry-university collaboration; The information between industry and university is not smooth, and the R\&D results are difficult to achieve sharing.

Collaborative Objectives. There are great differences in the goal orientation between the two sides of the industry-university collaboration. When there are serious differences in the goal orientation between the two sides, there will be a lack of motivation for collaboration.

Distribution of Collaborative Interests. The two sides are in different industries, different fields and different systems. The two sides have different understanding of the value of technological achievements and their industrialization. Because of the lack of mechanism of sharing interests and risks, the two sides can not guarantee collaborative credit for a long time.

Insufficient Intellectual Capital in Enterprises. Enterprise innovation ability can not be 
developed systematically, most enterprises' technological innovation can not span the development stage of imitation learning and partial improvement, and can not play the role of innovation subject in collaboration.

Collaboration Mechanism. At present, China's industry and university collaboration mechanism is mainly based on contractual collaboration such as technology transfer, collaborative development and entrustment development. Due to the lack of long-term collaboration and strategic alliance, not only the duration of industry-university collaboration is relatively short, but also the level of collaboration is low. It is difficult to improve the intellectual capital and innovation performance of enterprises, let alone promote the innovation of intellectual capital of the whole industry, regional industry and even the country.

In the past research field of industry-university collaboration, the research on phenomena research and cooperative ecological environment has accumulated rich experience, but there are not many systematic analysis of the cross-organizational collaboration relationship between industry and university. There are very few studies have been done on the outcomes of the collaborations between industry and university. Or, even have the results from the research but they are less applicable used in practice.

In recent years, through the industry-university collaboration, the innovation ability of enterprises, especially high-tech enterprises, has been greatly improved, and Zhejiang province has become one of the famous economic provinces in China. Therefore, this study takes the collaborative relationship between industry and university as the research perspective, the high-tech enterprises which are active in industry-university collaboration as the research objects, to study the effects of different industry-university collaboration relationships on enterprises' intellectual capital. This study combines the research results with the specific regional environment, enriches the theory of industry-university synergy and intellectual capital, and provides a reference for local governments to formulate targeted science and technology innovation policies.

\section{Research Objectives}

1. To study the effects of industry-university collaboration on enterprises' intellectual capital.

2. To study the styles of industry-university collaboration relationships on enterprises' intellectual capital.

3. To study the success of industry-university collaboration in order to applying as enterprises' intellectual capital.

4. To study the success of cross-organizational management of industry-university collaboration effect of enterprises' intellectual capital.

\section{Conceptual Framework}

The aims of the current research are to study the effects of industry-university collaboration on enterprises' intellectual capital. The author has reviewed many books and academic 


\section{Macrothink}

International Journal of Human Resource Studies

ISSN 2162-3058 2020, Vol. 10, No. 1

journal articles and found that from the perspective of industry-university collaboration relationship, the factors that affect the intellectual capital of enterprises included joint $R \& D$, commissioned development, co-construction collaboration agency, collaborative training, and personnel exchange.

The author analyzes the information from books, texts, and academic journal articles and discovered the relationship between industries and universities factors. The author them attempts to find out the impact of different industry-university collaboration relationship on enterprises' intellectual capital. Therefore, the research conceptual framework was developed after a review of collaborative behavior between universities and industries in different countries as described by Tijssen, Perkmann and Walsh (2006). Therefore, the author summarizes and proposes the following conceptual framework:

Independent Variables

Dependent Variable

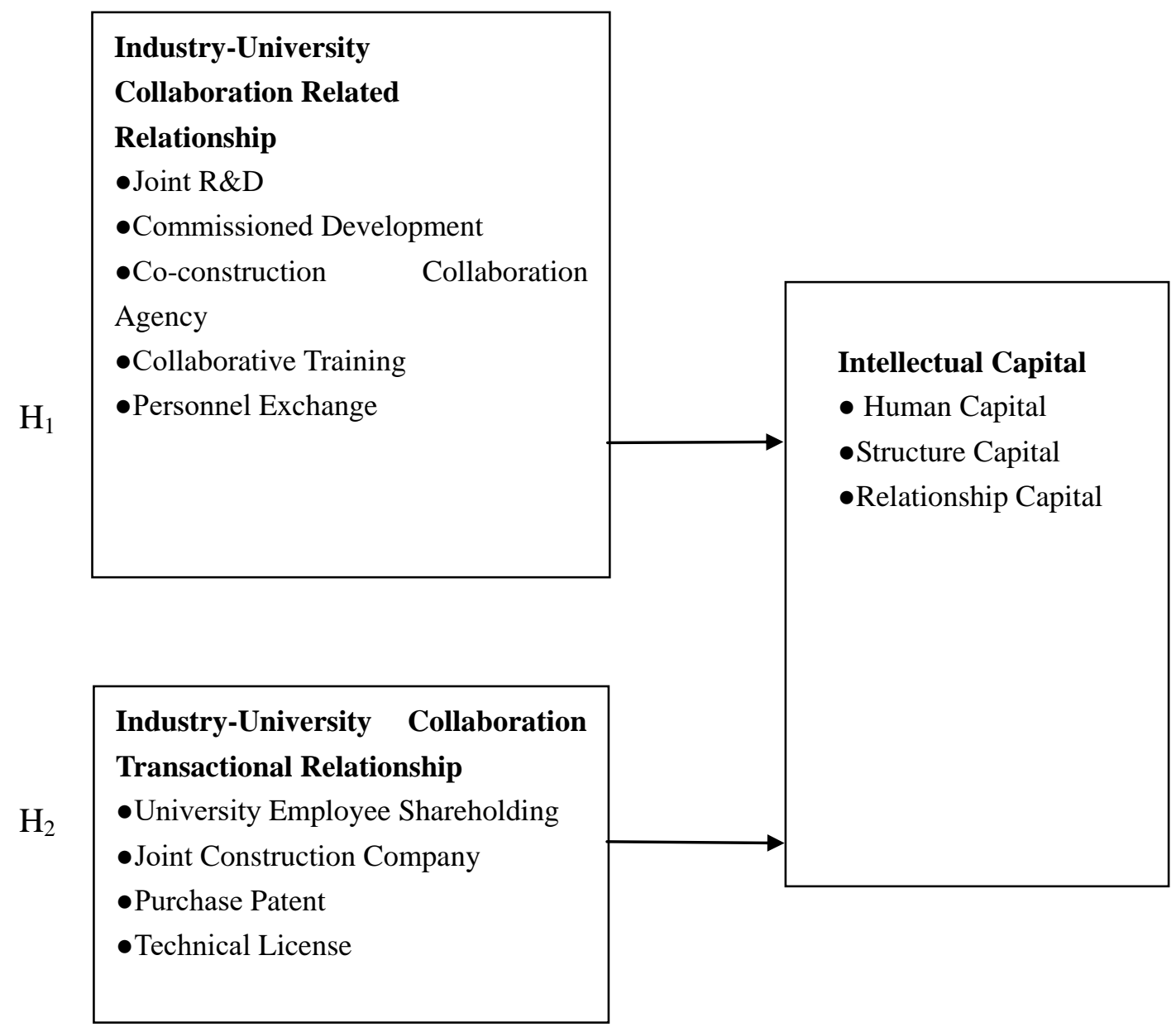

Figure1. Research Conceptual Framework

Source: the authors developed from Tijssen, Perkmann \& Walsh (2006)

\section{Research Hypothesis}

$\mathbf{H}_{1:}$ Relationship between universities and enterprises have a significant effects on enterprises' 


\section{Macrothink}

intellectual capital.

In order to further explore the impact of related relationship on enterprises' intellectual capital, this hypothesis includes the following three sub-hypotheses:

SubH1 $1_{\mathrm{a}}$ Related relationship have a significant effects on enterprises' human capital. (The stronger the related relationship is, the higher the enterprises' human capital is).

$\mathrm{SubH}_{1}$ : Related relationship have a significant effects on enterprises' structure capital. (The stronger the related relationship is, the higher the enterprises' structure capital is).

SubH1 $1_{\text {c: }}$ Related relationship have a significant effects on enterprises' relationship capital. (The stronger the related relationship is, the higher the enterprises' relationship capital is).

$\mathbf{H}_{2:}$ Transactional relationship between universities and enterprises have a significant effects on enterprises' intellectual capital.

$\mathrm{SubH} 22_{\mathrm{a}}$ Transactional relationship have a significant impact on enterprises' human capital. (The stronger the transactional relationship is, the higher the enterprises' human capital is).

$\mathrm{SubH} 2_{\mathrm{b}}$ : Transactional relationship have a significant impact on enterprises' structure capital. (The stronger the transactional relationship is, the higher the enterprises' structure capital is).

$\mathrm{SubH} 2_{\mathrm{c}}$ Transactional relationship have a significant impact on enterprises' relationship capital. (The stronger the transactional relationship is, the higher the enterprises' relationship capital is).

\section{Industry-University Collaboration Relationship}

Perkmann and Walsh (2007) combining with the design of open innovation, classified the industry-university collaboration relationship, boils down to link type, mobile type and move type three categories, at the same time, they also in the study, points out that this kind of classification has certain defects, for example, mobile type of academic activities have a direct relationship between the knowledge trading behavior, which belongs to the behavior in the transfer relationship. At the same time, the classification of human resource communication in their research is relatively vague. There are human resource interaction activities in mobile collaborative relationships, as well as in relational collaborative relationships, and they tend to attribute human resource communication activities to relational industry-university collaborative relations. 
Table 1. Types of Relationship Between Universities and Enterprises

The Scope of Relationship Involvement

High: Related types

R\&D parer
Low: Transfer types

Commercial (such as a

Technical license)

R\&D service

Human resource exchange

Scientific publishing/academic conferences and technological networks can cover the above three types of relations

Source: Perkmannm \& Walsh (2007)

Tijssen (2006) divided the evolution and development of industry-university collaboration into three stages, namely, application orientation, product orientation and business orientation, by studying the industry-university collaboration behaviors in different countries and aiming at entrepreneurial orientation, and defined it as science-based entrepreneurial orientation for universities. In the first stage, there is a sense of commercialization of technology in industry-university collaboration, but the purpose of industry-university collaboration is for its own scientific research needs; In the second stage, the university conducts research and development activities for the purpose of technology practicality, and has paid attention to the identification of technology commercialization opportunities; In the third stage, the connection of industry-university collaboration established the contract based on commercialization, and the university itself also paid attention to the development of technology commercialization opportunities and the protection of intellectual property rights. From the perspective of academic capitalization, this model divides the types of industry-university collaboration into three stages, which is of great significance for the analysis of industry-university collaboration.

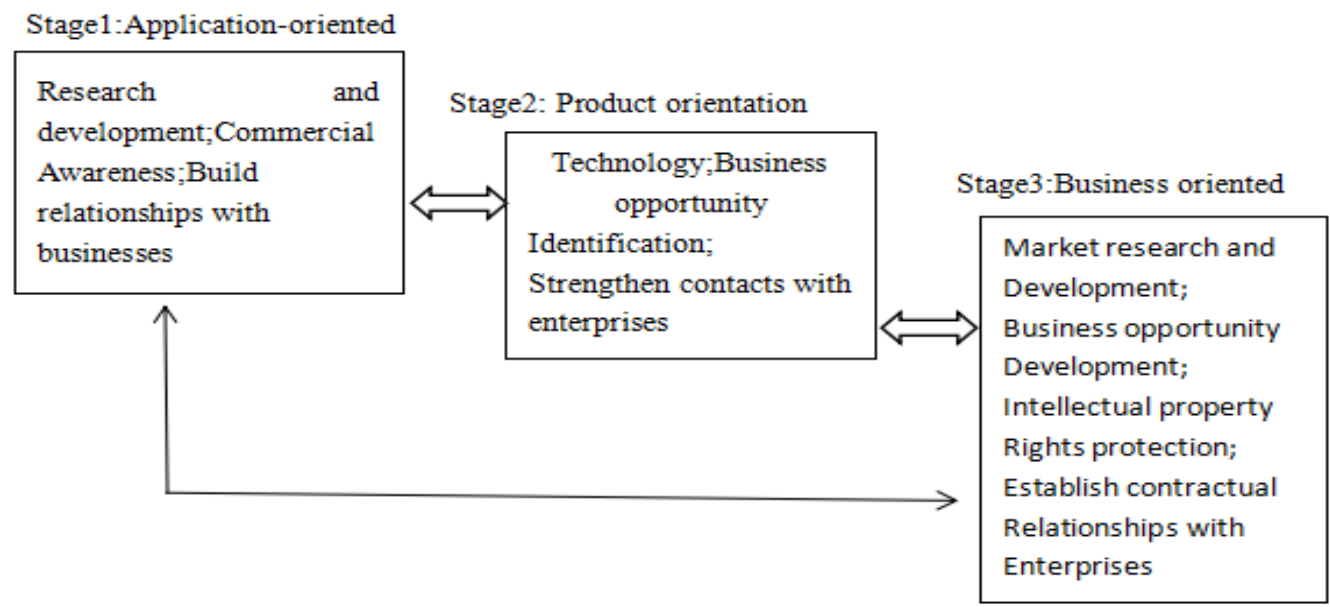

Figure 2. University is Based on the Scientific Entrepreneurial Orientation Model 
Source: Tijssen (2006)

In the evolution of the three-stage relationship model of Tijssen (2006), the boundary between the first and second stages is not very clear. Both application orientation and product orientation are based on the utility requirements of technology. In Perkmann and Walsh's (2007) theoretical model, these two stages can be defined as the establishment of related relationship between universities and enterprises. In general, the collaborative relationship between industry and university can be classified into contractual type and non-contractual type.

Table 2. Several Manifestations of Industry-University Collaboration

\begin{tabular}{|c|c|c|}
\hline & Contractual & Non-Contractual \\
\hline $\begin{array}{l}\text { Knowledge } \\
\text { Level }\end{array}$ & $\begin{array}{l}\text { Technology transfer } \text { (technology } \\
\text { licensing, technology trading, joint } \\
\text { research and development, } \\
\text { commissioned development, etc.) }\end{array}$ & $\begin{array}{l}\text { Academic } r \text { exchanges } \\
\text { (international conferences, joint } \\
\text { publications, technical exchanges, } \\
\text { etc.) }\end{array}$ \\
\hline $\begin{array}{l}\text { Individual } \\
\text { Level }\end{array}$ & Employment, Joint training, Training & Informal communication \\
\hline $\begin{array}{l}\text { Organization-al } \\
\text { Level }\end{array}$ & $\begin{array}{l}\text { New economic entities, Joint research } \\
\text { and development center }\end{array}$ & Donation \\
\hline
\end{tabular}

Source: according to relevant literature.

By analyzing the motivation of industry-university collaboration and the law of knowledge transfer, Bonaccorsi and Piccaluga (1994) divided the cross-organizational collaborative relationship between universities and enterprises into two dimensions: structural dimension and procedural dimension. Institution arrangement is a formal industry-university collaboration arrangement established based on series of agreements or contracts; Coordinating Procedures are standards of conduct occurring in the course of an interaction between industries. From the perspective of cycles, these forms of industry-university collaboration are closer to the stage of technology commercialization and more in line with the essential needs of industry-university collaboration. However, there are significant differences in the ways in which the main body of collaborative activities obtain intellectual capital. In combination with the foregoing, on the basis of Tijssen (2006), Perkmann and Walsh (2007) and other research results, the industry-university collaboration can be divided into two types.

The first is the related relationship, which is a collaborative relationship based on cross-organizational knowledge exchange and utility knowledge production. The second is transactional relationship, which is a collaborative relationship based on the 
commercialization of knowledge among organizations. (Tijssen, 2006; Perkmann, Walsh, 2007)

\section{Intellectual Capital}

The definition of intellectual capital in this study is the value of a company including employee knowledge, skills, capability, and resources that an organization has or can manage to create value and gain sustainable competitive advantage for the organization. It has three dimensions: human capital, structure capital and relationship capital. (Galbrainth, Petty, Guthrie, 2000)

\section{Research Methodology}

This research is designed as a quantitative research using survey questionnaire as the main tool to collect primary data from the sample groups. The enterprises selected high-tech enterprises in Zhejiang Province, mainly selected by corporate legal persons and industry-university collaboration project executives as the key questionnaires. We distributed 90 questionnaires to EMBA and MBA students (high-tech enterprise legal persons or senior executives) from Zhejiang University, Zhejiang Gongshang University and Hangzhou University of Technology whereas 240 questionnaires were distributed to the senior executives of the industry-university collaboration project of Zhejiang University Science Park and Hangzhou University of Technology High-tech Zone. The rest 120 questionnaires were distributed through the Industry-university collaboration offices of the universities in Hangzhou, Ningbo, Shaoxing, Jiaxing and Wenzhou. A total of 450 questionnaires were distributed to collect the data for this research. The questionnaires on the recycling were sorted out, and found that 44 questionnaires were incomplete, so they were excluded. The remaining 406 valid questionnaires still meet the requirements of the empirical analysis sample size. Thus, the research results were based on 406 samples.

The study uses multiple regressions analysis to test the relationships of variables among industry-university collaboration and enterprises' intellectual capital, and to test the research hypothesis.

\section{Research Findings}

Effects of Industry-University Collaboration Relationship on Enterprises' Human Capital. In this paper, the regression analysis on the relationship between industry-university collaboration and intellectual capital would be analyzed by using SPSS software. After the previous correlation analysis, it has been found that the related relationship and the transactional relationship have significant with human capital, which is recorded as X1 X2 as independent variables, human capital as dependent variable, and recorded as Y, for regression analysis. The selected equation form is a multiple linear regression equation, which is set to:

$$
\mathrm{Y}=\mathrm{b} 0+\mathrm{b} 1 * \mathrm{X} 1+\mathrm{b} 2 * \mathrm{X} 2+\mathrm{u}
$$

Perform regression analysis. The following analysis results were obtained. 
Table 3. Regression Result

\begin{tabular}{|c|c|c|c|c|c|c|c|}
\hline \multirow{3}{*}{$\frac{\text { Model }}{1(\text { Constant })}$} & \multicolumn{2}{|c|}{$\begin{array}{l}\text { Unstandardized } \\
\text { Coefficients }\end{array}$} & \multicolumn{2}{|c|}{$\begin{array}{l}\text { standardized } \\
\text { Coefficients }\end{array}$} & \multirow[b]{2}{*}{ Sig. } & \multicolumn{2}{|c|}{$\begin{array}{l}\text { Collinearity } \\
\text { Statistics }\end{array}$} \\
\hline & B & Std. Error & Beta & $\mathrm{t}$ & & Toler & VIF \\
\hline & -.534 & .246 & & -2.170 & .031 & & \\
\hline RR Total & .360 & .137 & .210 & 2.633 & $.009 * *$ & .251 & 3.977 \\
\hline TR Total & .693 & .136 & .407 & 5.107 & $.000 * *$ & .251 & 3.977 \\
\hline
\end{tabular}

There may be multiple col linearity of the variables in the test model. Multicollinearity refers to the fact that the model estimates are distorted or difficult to estimate accurately due to the existence of exact correlations or high correlations between explanatory variables in linear regression models. We learned through SPSS analysis that the maximum VIF (Variance Inflation) of the variance expansion factor is 3.977 , which is in accordance with the standard of $0 \sim 10$. From Table 3, it can be found that the regression coefficient of the related and transactional relationship is significantly different from zero $(\mathrm{Sig}<0.05)$ by the significance test, and the regression coefficient of the "related relationship" is 0.360 . The regression coefficient of the "transactional relationship" is 0.693 , which indicates that the transactional relationship has a significant positive impact on human capital, and its influence coefficient is 0.693 .

Therefore, the multiple regression equation between the related relationship and transactional relationship to human capital can be summarized as:

$$
\mathrm{Y}=-0.534+0.360 * \mathrm{X} 1+0.693 * \mathrm{X} 2
$$

The regression equation shows that under the other conditions, the human capital is increased by 0.360 units for each unit of the related relationship, and the human capital is increased by 0.693 units for each unit of the transactional relationship. The relationship between the related and transactional have a positive impact on the enterprises' human capital, assuming that $\mathrm{H}_{\mathrm{a}}$ and $\mathrm{H} 2_{\mathrm{a}}$ is established. This result shows that the higher the intensity of the industry-university collaboration relationship, the better the quality and ability of the employees.

Effects of Industry-University Collaboration Relationship on Enterprises' Structure Capital. It has been known from the previous correlation analysis that the related relationship and the transactional relationship have significant correlations with structure capital, which are recorded as $\mathrm{X} 1 \sim \mathrm{X} 2$ as independent variables, structure capital as dependent variable, and recorded as $\mathrm{Y}$, for regression analysis. The selected equation form is a multiple linear 
regression equation, which is set to:

$$
\mathrm{Y}=\mathrm{b} 0+\mathrm{b} 1 * \mathrm{X} 1+\mathrm{b} 2 * \mathrm{X} 2+\mathrm{u}
$$

Perform regression analysis, get the following analysis results:

Table 4. Regression Result

\begin{tabular}{|c|c|c|c|c|c|c|c|}
\hline \multirow{3}{*}{$\begin{array}{l}\text { Model } \\
1(\text { Constant })\end{array}$} & \multicolumn{2}{|c|}{$\begin{array}{l}\text { Unstandardized } \\
\text { Coefficients }\end{array}$} & \multicolumn{2}{|c|}{$\begin{array}{l}\text { standardized } \\
\text { Coefficients }\end{array}$} & \multirow[b]{2}{*}{ Sig. } & \multicolumn{2}{|c|}{$\begin{array}{l}\text { Collinearity } \\
\text { Statistics }\end{array}$} \\
\hline & B & Std. Error & Beta & $\mathrm{t}$ & & Toler & VIF \\
\hline & -.253 & .223 & & -1.136 & .257 & & \\
\hline RR Total & .650 & .124 & .406 & 5.242 & .000 & .251 & 3.977 \\
\hline TR Total & .382 & .123 & .240 & 3.100 & .002 & .251 & 3.977 \\
\hline
\end{tabular}

The multiple regression equation between the related relationship and transactional relationship to structural capital can be summarized as:

$$
\mathrm{Y}=-0.253+0.650 * \mathrm{X} 1+0.382 * \mathrm{X} 2
$$

The regression equation shows, all else being equal, the related relationship is increased by one unit, the structural capital is increased by 0.650 units; the transactional relationship is increased by one unit, and the structure capital is increased by 0.382 units. The results show that enterprises attach importance to the management of industry-university collaboration relationship, which have a positive impact on the structure capital of enterprise knowledge reserve, process system, corporate culture, etc., assuming $\mathrm{H} 1_{\mathrm{b}}$ and hypothesis $\mathrm{H} 2_{\mathrm{b}}$ are established.

Effects of Industry-University Collaboration Relationship on Enterprises' Relationship capital. The selected equation form is a multiple linear regression equation, which is set to:

$$
\mathrm{Y}=\mathrm{b} 0+\mathrm{b} 1 * \mathrm{X} 1+\mathrm{b} 2 * \mathrm{X} 2+\mathrm{u}
$$

A regression analysis was performed to obtain the following analysis results. 
Table 5. Regression Result

\begin{tabular}{|c|c|c|c|c|c|c|c|}
\hline \multirow{3}{*}{$\frac{\text { Model }}{1(\text { Constant })}$} & \multicolumn{2}{|c|}{$\begin{array}{l}\text { Unstandardized } \\
\text { Coefficients }\end{array}$} & \multicolumn{2}{|c|}{$\begin{array}{l}\text { standardized } \\
\text { Coefficients }\end{array}$} & \multirow[b]{2}{*}{ Sig. } & \multicolumn{2}{|c|}{$\begin{array}{l}\text { Collinearity } \\
\text { Statistics }\end{array}$} \\
\hline & B & Std. Error & Beta & $\mathrm{t}$ & & Toler & VIF \\
\hline & 1.192 & .198 & & 6.017 & .000 & & \\
\hline RR Total & .385 & .110 & .263 & 3.769 & .000 & .251 & 3.977 \\
\hline TR Total & .031 & .109 & .022 & 1.230 & .056 & .251 & 3.977 \\
\hline
\end{tabular}

The multiple regression equation between the related relationship and transactional relationship to the relationship capital can be summarized as:

$$
\mathrm{Y}=1.192+0.385 * \mathrm{X} 1
$$

The regression equation shows that under the condition of constant condition, the relationship capital increases by 0.385 units for each unit of related relationship increase. It shows that enterprises attach importance to the management of related industry-university collaboration relationship, which have a positive impact on corporate relationship capital, assuming $\mathrm{H} 1_{\mathrm{c}}$ is established. The transactional industry-university collaboration relationship have no significant impact on relationship capital, assuming that $\mathrm{H} 2_{\mathrm{c}}$ has not been verified.

\begin{tabular}{|c|c|c|c|}
\hline $\begin{array}{l}\text { Serial } \\
\text { Number }\end{array}$ & \multicolumn{2}{|c|}{ Hypothesis } & Results \\
\hline \multirow[t]{4}{*}{ H1 } & \multicolumn{2}{|r|}{$\begin{array}{l}\text { Relationship between universities and enterprises have a significant } \\
\text { influence on the enterprises' intellectual capital }\end{array}$} & Accepted \\
\hline & $\mathrm{H} 1_{\mathrm{a}}$ & $\begin{array}{l}\text { Related relationship have a significant influence on } \\
\text { enterprises' human capital. The stronger the related } \\
\text { relationship is, the higher the enterprises' human capital is. }\end{array}$ & Accepted \\
\hline & $\mathrm{H} 1_{\mathrm{b}}$ & $\begin{array}{l}\text { Related relationship have a significant influence on } \\
\text { enterprises' structure capital. The stronger the related } \\
\text { relationship is, the higher the enterprises' structure capital is. }\end{array}$ & Accepted \\
\hline & $\mathrm{H} 1_{\mathrm{c}}$ & $\begin{array}{l}\text { Related relationship have a significant influence on } \\
\text { enterprises' relationship capital. The stronger the related }\end{array}$ & Accepted \\
\hline
\end{tabular}




\begin{tabular}{|l|l|l|l|}
\hline & \multicolumn{2}{|c|}{$\begin{array}{l}\text { relationship is, the higher the enterprises' relationship capital } \\
\text { is. }\end{array}$} & \\
\hline $\mathrm{H} 2$ & $\begin{array}{l}\text { Transactional relationship between universities and enterprises have } \\
\text { a significant influence on the enterprises' intellectual capital }\end{array}$ & $\begin{array}{l}\text { Partially } \\
\text { Accepted }\end{array}$ \\
\hline $\mathrm{H} 2_{\mathrm{a}}$ & $\begin{array}{l}\text { Transactional relationship have a significant impact on } \\
\text { enterprises' human capital. The stronger the transactional } \\
\text { relationship is, the higher the enterprises' human capital is. }\end{array}$ & Accepted \\
\hline $\mathrm{H} 2_{\mathrm{b}}$ & $\begin{array}{l}\text { Transactional relationship have a significant impact on } \\
\text { enterprises' structure capital. The stronger the transactional } \\
\text { relationship is, the higher the enterprises' structure capital is. }\end{array}$ & Accepted \\
\hline $\mathrm{H} 2_{\mathrm{c}}$ & $\begin{array}{l}\text { Transactional relationship have a significant impact on } \\
\text { enterprises' relationship capital. The stronger the } \\
\text { transactional relationship is, the higher the enterprises' } \\
\text { relationship capital is. }\end{array}$ & Rejected \\
\hline
\end{tabular}

\section{Conclusion}

The results from descriptive analysis used to analyze factors effects of industry-university collaboration on enterprises' intellectual capital. The results found that the related industry-university collaboration relationship has a positive impact on the company's intellectual capital (assuming $\mathrm{H}_{1}$ is established), and the company attaches importance to the management of related relationship such as joint R\&D, commissioned development, personnel exchange, collaborative training, and co-construction collaboration agency. It has a positive impact on the improvement of enterprises' intellectual capital. From the literature analysis of the previous article, it can be seen that the related industry-university collaboration relationship has two types of activities, contractual and non-contractual, and non-contractual activities include personnel exchanges and talent exchange activities. This plays a very important role in building the relationship capital dimension of enterprises' intellectual capital.

The transactional industry-university collaboration relationship has a positive impact on human capital and structure capital (assuming $\mathrm{H}_{2}$ is partially passed, $\mathrm{H} 2_{\mathrm{a}}$ and $\mathrm{H} 2_{\mathrm{b}}$ are established), and there is no significant positive impact on relationship capital ( $\mathrm{H} 2_{\mathrm{c}}$ does not hold). Why is there no significant positive impact of transactional relationship on corporate relationship capital? One of the most important reasons is that transactional industry-university collaboration relationship lack non-contractual activities. And in a modern business society, non-contractual activities have a very important positive orientation for the maintenance of corporate social image and supplier relationship. At the same time, it has a very important positive promotion effect on user experience and product satisfaction. The regression analysis of the industry-university collaboration relationship on intellectual capital 


\section{Macrothink}

International Journal of Human Resource Studies

ISSN 2162-3058 2020, Vol. 10, No. 1

also confirms this view. The positive impact of a transactional relationship that lacks non-contractual activities on corporate relationship capital is not significant.

According to the empirical analysis of the impact of industry-university collaboration on enterprises' intellectual capital, industry-university collaboration can effectively promote the improvement of enterprises' intellectual capital. The construction of the related relationship based industry-university collaboration relationship can effectively promote the accumulation of intellectual capital. Therefore, enterprises should pay attention to the industry-university collaboration management of related relationship, strengthen joint $R \& D$, commissioned development, personnel exchange, collaborative training, and co-construction collaboration agency, and enhance the core competitiveness of enterprises (intellectual capital) by implementing effective cross-organizational management.

Based on the above empirical results and the interaction mechanism analysis of two different types of industry-university collaboration relationship, the mechanism of the influence of industry-university collaboration on enterprises' intellectual capital is obtained (Fig. 3).

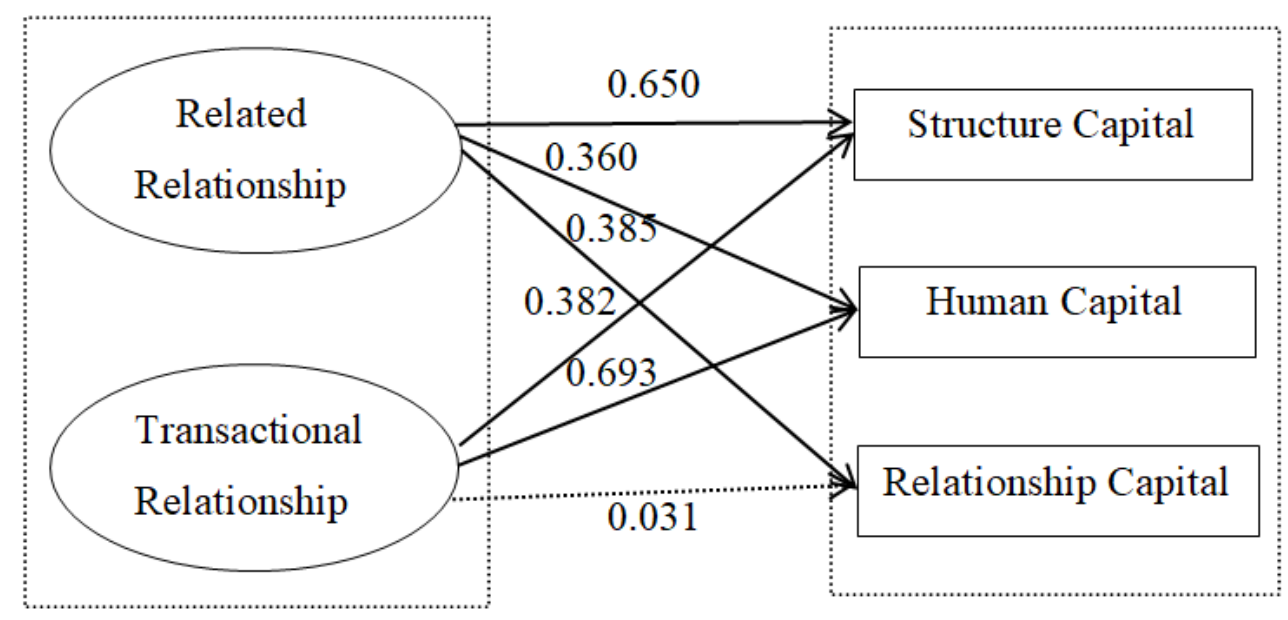

Integration of Industry-University Collaboration

Intellectual Capital

Figure 3. Mechanism of the Integration of Industry-University Collaboration on Intellectual Capital

Source: researcher developed from test results

First, Industry-University Collaboration Should Focus on the Development of Enterprise R\&D Capabilities and Enhance Enterprises' Structure Capital. From the conclusions of this study, it can be seen that relying too much on the research and development strength of universities cannot effectively improve the product innovation ability of enterprises, innovative policies that advocate the transformation of scientific and technological achievements in universities cannot solve the problem of insufficient innovation capability of enterprises from a fundamental and long-term perspective. The cost of technology introduction in China's enterprises accounts for more than $90 \%$ of the total funds, and the cost of digesting and innovating is less than $10 \%$. We should attach great importance to the joint innovation and research, the secondary innovation of the entrusted development, the 
original innovation model, enhance the R\&D capability of the enterprise, and build an efficient and reasonable Technological innovation system. The government supports the establishment of enterprise technology centers, stimulates the enthusiasm of university researchers to participate in enterprise $R \& D$ activities, and supports the establishment of university-enterprise collaborative innovation centers, promote personnel interaction and knowledge exchange between universities and enterprises, and realize the rapid improvement of enterprise R\&D capability and the good accumulation of corporate structural capital.

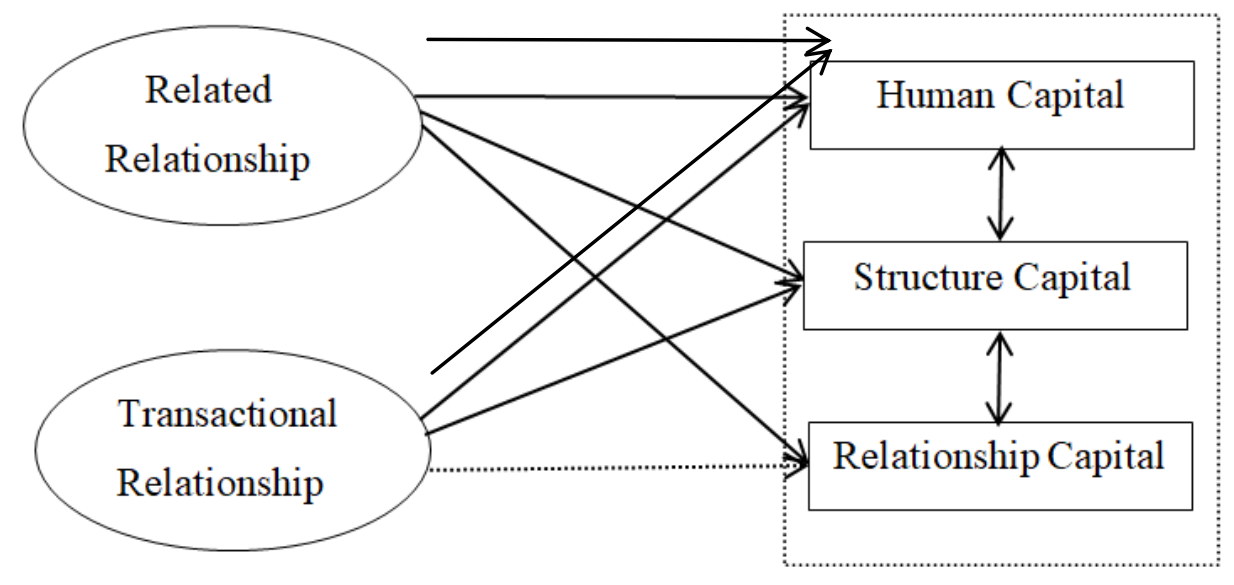

Integration of Industry-University Collaboration Intellectual Capital

Figure 4. Policy Design Logic of Industry-University Collaboration in R\&D Capacity

Source: author developed from various sources of information

Second, Industry-University Collaboration Should Focus on The Training of Leading Talents and Enhance Enterprises' Human Capital. Through the research and development model of industry-university collaboration, a group of leading talents (human capital) with advanced technological capabilities will be cultivated, which will play an important role in promoting the intellectual capital of enterprises. First of all, in the strategy of capacity building for higher education, the education and training of management and marketing talents should be placed in the same important position as the development of talents and the education of outstanding engineers. Combined with this research, the industry-university collaboration is not only reflected in the research and development capabilities, the contribution of knowledge products, but also in the cultivation of human capital through management and marketing, which can improve the financial performance of enterprises. Therefore, higher education should get rid of the traditional thinking of cultivating "excellent engineers" and attach importance to improving the training ability and quality of education management talents and marketing talents. 


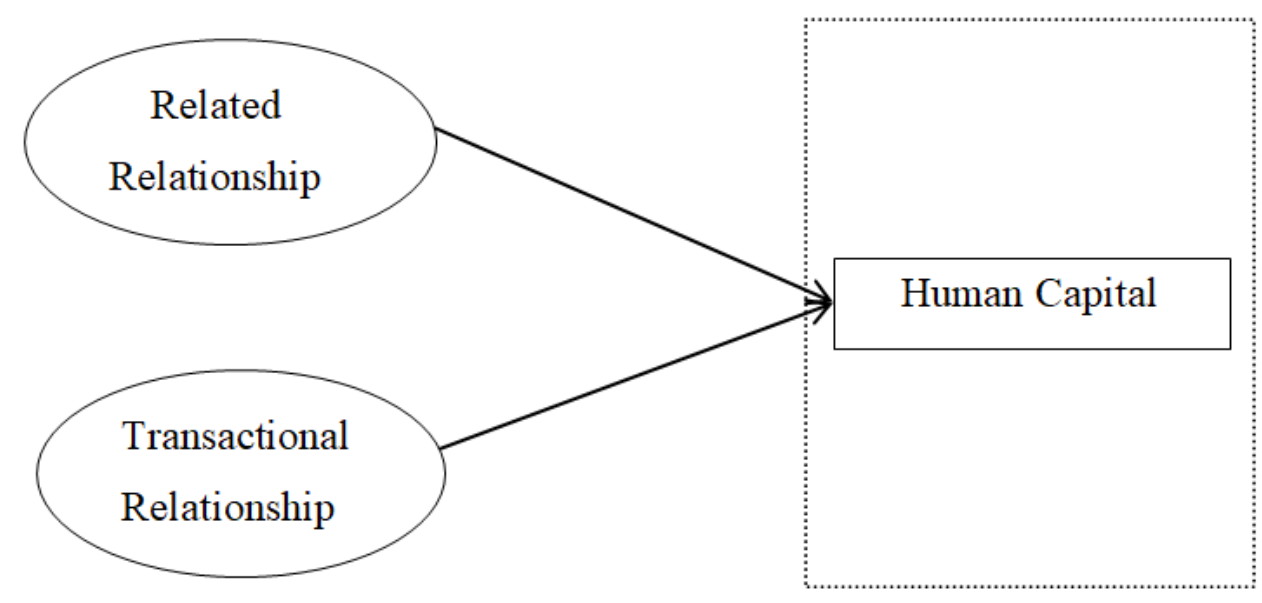

Integration of Industry-University Collaboration

Intellectual Capital

Figure 5. Policy Design Logic of Industry-University Collaboration in Leading Talents

Source: author developed from various sources of information

Third, industry-university collaboration should focus on establishing a network of collaborative resources and enhancing enterprises' relationship capital. University is not only the most important source of external intellectual capital available to companies, but also the bridge and link for companies to further connect with a wider range of intellectual capital. According to the conclusion of this study, the establishment and management of related industry-university collaboration relationships can effectively improve the capital of corporate relations and thus have a positive impact on corporate intellectual capital. First, the historical mission of modern universities has given them more functions. The inherent needs of their own development have promoted the establishment of closer links between universities and external sources of knowledge, tracking the world's most cutting-edge scientific and technological information, universities and universities, universities and enterprises. It has been linked into a network of extensive knowledge and talent exchanges; Second, as a public welfare education, research and social service institution, the university has a low barrier to external resources, which promotes the breadth and intensity of resource linkage. Therefore, the policy to support enterprise and university joint development, personnel exchanges and establish a joint research and development center and other associative relationship between colleges management, especially the support industry leading enterprises, the large-scale enterprises and universities to establish co-operative carrier (collaborative innovation center), a type related with university of sustained and stable relationship, for enterprise development to provide a steady stream of intellectual capital resources. 


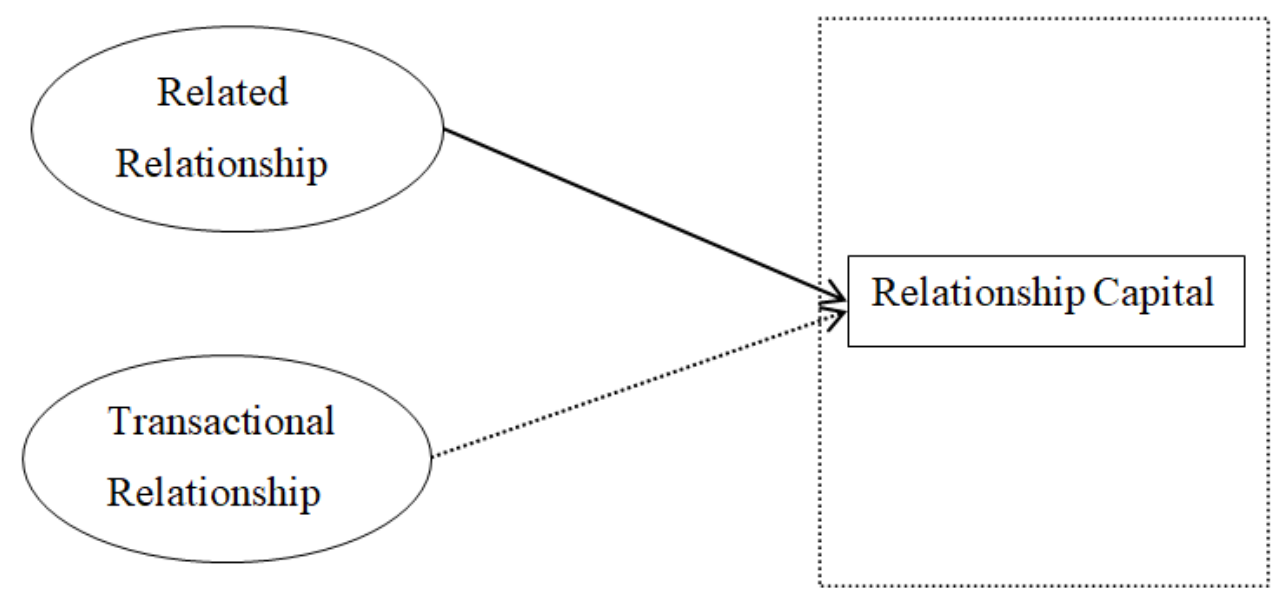

Integration of Industry-University Collaboration

Intellectual Capital

Figure 6. Policy Design Logic of Related Industry-University Collaboration Resource Network

Source: author developed from various sources of information

Fourthly, We Should Build A Mufti - Level Government Management System of Industry-University Collaboration to Enhance Enterprises' Intellectual Capital. The establishment of industry-university collaboration management systems and policies is an important guarantee and basis for guiding the will and behavior of industry-university collaboration. Under the conditions of market economy, the difficulties and problems in solving the industry-university collaboration mainly depend on the market mechanism. However, this does not mean that the government can ignore it. Without the participation of the government, it is difficult for both parties to cooperate in long-term deep collaboration. Therefore, the management mechanism of industry-university collaboration can be implemented by constructing a multilevel government management system. The first level is the construction of the decision-making system at the national level, the second level is the establishment of the local provincial decision-making system, the third level is the operational level of industry-university collaboration, the operational level of industry-university collaboration consists of industry associations, teaching guidance committees of all levels of education, collaborative enterprises and universities. In a word, industry-university collaboration should be based on market requirements, keep industry-university collaboration in the market, ensure the good operation of joint institutions through standardized and effective scientific management, promote the development of disciplines in universities, improve the level of scientific research in enterprises, and enhance the enterprises' intellectual capital.

\section{Research Implication}

Industry-university collaboration is a natural organizational form of corporate intellectual capital innovation. Therefore, industry-university collaboration is a form of technological innovation organized by countries all over the world, and it is also a continuing hot issue in 
academic research. The research implication may have the following aspects:

Taking the industry-university collaboration relationship as a research perspective may become the innovation of this research. In terms of research perspectives, scholars' research on industry-university collaboration mainly focuses on research from a macro perspective and a micro perspective. Based on the macro perspective of national innovation systems, the differences in regional development are neglected, and the results will lead to general or general policy recommendations, and the problem-solving is less targeted. Based on the analysis of the micro perspective of enterprises, the management of industry-university collaboration projects is of great practical significance, but the guiding significance of the formulation of public policies will be too personal and lose the universality. Based on the analysis of the regional innovation system, it is limited by geographical regions, lacks the vision of international competition, and contradicts the current economic environment of global economic integration. Therefore, this thesis attempts to use the industry-university collaboration relationship as a research perspective, and to study the high-tech enterprises with active industry-university collaboration in Zhejiang Province as the research scope, to study the influence of different industry-university collaboration on enterprises' intellectual capital, and to combine mature research results with The regional special environment is combined to enrich the regional intellectual capital innovation system theory and the industrial innovation system theory, which provides a reference for the local government to formulate targeted science and technology policies.

The conclusions of this paper may be an innovation in the development of the theory of industry-university collaboration in the field of intellectual capital. In terms of research content, industry-university collaboration is mainly limited to issues such as strategy and organizational management, dynamic mechanism, and collaboration barriers. It focuses on several research perspectives such as entrepreneurial university theory, innovation system theory, and knowledge management theory. Because the scholars' research is mainly based on the legal system of comparative system, complete intellectual property rights, technology transfer, etc. in the developed countries, the highly mature external environment under the highly developed factor market system, and the research strength of the universities in developed countries and the corresponding development of enterprises. Specific conditions such as demand, research on the law of industry-university collaboration in their respective environments, so comprehensive imitation does not conform to China's current actual situation, and the guiding significance of China's industry-university collaboration is very limited. This paper proves through empirical research that at the current stage, the industry-university collaboration relationship is the key factor affecting the innovation of enterprise intellectual capital.

In terms of solution design, it is innovative compared with the current policies in Zhejiang Province. Based on the research conclusions of the current industry-university collaboration mainly driven by factors, this paper analyzes the status quo of the industry-university collaboration policy in Zhejiang Province, puts forward the policy objectives and basic principles of the industry-university collaboration at this stage, and studies the collaboration between industry and university. Policy tools and measures for intellectual capital innovation. 


\section{Macrothink}

International Journal of Human Resource Studies ISSN 2162-3058 2020, Vol. 10, No. 1

Finally, it puts forward a specific solution to build a related industry-university collaboration relationship and promote enterprise intellectual capital innovation in the current environment.

\section{Limitation of the Study}

Due to limitations in language, profession, time, etc., this research ability is seriously insufficient; Research samples and regions are not rich enough. Due to geographical differences, the industry-university collaboration in each province is different, so the research results are not necessarily Suitable for all places; There are many factors affecting the intellectual capital of enterprises in the industry-university collaboration, due to the researcher limited ability, the model still needs to be developed and improved by the later researchers.

\section{References}

Bjerregard. (2014). Syncytin-1 in differentiating human myoblasts: relationship to caveolin-3 and myogenin. Cell and tissue research, 357(1), 355-362. https://doi.org/10.1007/s00441-014-1930-9

Boardman. (2008). Public_-Private Partnerships: Eight Rules for Governments. Public Works Management \& Policy, 13(2), 149-161. https://doi.org/10.1177/1087724X08323843

Bonaccorsi, A., \& Piccaluga, A. (1994). A theoretical framework for the evaluation of university-industry relationships. $R \& D$ Management, 24(3), 229-247. https://doi.org/10.1111/j.1467-9310.1994.tb00876.x

Daghfous. (2004). Absorptive capacity and the implementation of knowledge-intensive best practices. SAM Advanced Management Journal, 69(2), 21.

Gassol. (2007). The effect of university culture and stakeholders' perceptions on university-business linking activities. The Journal of Technology Transfer, 32(5), 489-507. https://doi.org/10.1007/s10961-007-9035-1

Galbraith. (2000). A services-marketing perspective on e-retailing: implications for e-retailers and directions for further research. Internet Research.

Johnson. (2008). SNAP: a web-based tool for identification and annotation of proxy SNPs using HapMap. Bioinformatics, 24(24), 2938-2939. https://doi.org/10.1093/bioinformatics/btn564

Nonaka, \& Takeuchi. (1995). The knowledge-creating company: How Japanese companies create the dynamics of innovation. Oxford university press. https://doi.org/10.1016/0024-6301(96)81509-3

Organisation for Economic Co-operation and Development (OECD). (1996). OECD employment outlook: July 1996. OECD, Paris, France.

Porter, G. (1999). Trade competition and pollution standards: "race to the bottom" or "stuck at the bottom". The Journal of Environment \& Development, 8(2), 133-151. https://doi.org/10.1177/107049659900800203 


\section{Macrothink}

International Journal of Human Resource Studies

ISSN 2162-3058 2020, Vol. 10, No. 1

Perkmann, M., \& Walsh, K. (2007). University-industry relationships and open innovation: Towards a research agenda. International journal of management reviews, 9(4), 259-280. https://doi.org/10.1111/j.1468-2370.2007.00225.x

Petty, R., \& Guthrie, J. (2000). Intellectual capital literature review. Journal of intellectual capital. https://doi.org/10.1108/14691930010348731

Tijssen. (2006). Universities and industrially relevant science: Towards measurement models and indicators of entrepreneurial orientation. Research Policy, 35(10), 1569-1585. https://doi.org/10.1016/j.respol.2006.09.025

\section{Copyright Disclaimer}

Copyright for this article is retained by the author(s), with first publication rights granted to the journal.

This is an open-access article distributed under the terms and conditions of the Creative Commons Attribution license (http://creativecommons.org/licenses/by/4.0/). 